\title{
The Resonance of Colonial Era Customary Codes in Contemporary Uganda
}

\section{P.E.R}

Pioneer in peer-reviewed, open access online law publications

Author

David Dennison

Affiliation

Uganda Christian University

Faculty of Law, Uganda

Email dbriandennison@gmail.com

Date Submission

21 February 2019

Date Revised

28 August 2019

Date Accepted

13 October 2019

Date published

12 December 2019

Guest Editors

Ms F Osman and Prof C Himonga

How to cite this article

Dennison DB "The Resonance of Colonial Era Customary Codes in Contemporary Uganda" PER/

PELJ 2019(22) - DOI

http://dx.doi.org/10.17159/17273781/2019/v22i0a7587

\section{Copyright}

DOI

http://dx.doi.org/10.17159/1727-

3781/2019/v22i0a7587

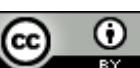

\begin{abstract}
Colonial era codifications of customary law - especially those codified in indigenous first languages - have a resilient capacity to form and inform living customary law. In the context of Mukono District, Uganda, modern conceptions of customary law are informed and shaped by colonial era codifications promulgated by the British Protectorate and the Kingdom of Buganda. This research insight offers practical benefits to those seeking to promote access to justice and human rights development in Mukono District. Such benefits speak to the potential vitality and relevance of colonial era customary codifications. Misgivings about the alien influences and exploitative purposes that distorted and corrupted colonial era codes do not warrant disregard of their active legacy within modern customary legal frameworks. The use of receptive research approaches such as those developed and modelled by Sally Falk Moore can help ensure the ongoing influence of colonial era codes are not hidden by contemporary orthodoxies and biases.
\end{abstract}

\section{Keywords}

Customary law; recording customary law; colonial codification; colonialism; post-colonialism; semi-autonomous social field; legal anthropology; legal pluralism; Kabaka; Uganda; Buganda; Baganda; Mukono District. 


\section{Introduction}

Discerning customary law in post-colonial contexts requires careful attention to detail and nuance. The process is highly situational and varies based on history, culture, time and place. Contextual specificity and receptiveness to a broad array of sources and influences is critical when discerning the lived law in post-colonial contexts.

A growing appreciation of deep legal pluralism and Sally Falk Moore's ${ }^{1}$ semi-autonomous social field approach has led researchers to cast wide nets when determining what sources contribute to community-level legal norms and practices. Yet, despite the rise of inclusive research approaches, there are legal sources that receive little notice or recognition. This paper concerns one such source - colonial era codifications of customary law.

This paper makes the case for the continuing resonance and significance of colonial era customary codifications in modern-day Mukono District, Uganda. It begins with a contextual introduction. Next, it outlines reasons why colonial era customary codifications are overlooked and disregarded. The paper then recounts the research approach, literature review and field work outputs that led the author to take account of colonial era customary codifications in Mukono District. That is followed with postulations as to why colonial era customary codifications remain effectual and resilient within Mukono's customary legal frameworks. The paper concludes with a discussion of the implications and applications of the core research findings.

\section{Colonialism and the recoding of customary law in Africa}

When European colonialists ventured into Africa, they encountered unwritten indigenous laws and legal systems. The clash of colonising cultures resulted in a somewhat predictable response - the written formalisation of indigenous law by European hook, crook or code. ${ }^{2}$

Multiple motives were behind European efforts to record indigenous laws. The colonialists were culturally predisposed to see the written law as superior to the unwritten law. Europeans had a historically rooted bias

David Brian Dennison. PhD (UCT) BA MBA JD (U Georgia). Adjunct Professor, Regent School of Law, Virginia Beach, Virginia, USA. Former senior lecturer and acting dean, Uganda Christian University Faculty of Law, Uganda. Email: dbriandennison@gmail.com.

Moore 1973 Law \& Soc'y Rev 745.

See generally Bennett and Vermeulen $1980 \mathrm{~J}$ Afr L; Shadle $1999 \mathrm{JAH}$ for critical treatments of colonial era indigenous codification efforts. 
towards written legal systems that traced back to Roman Civil Law and Justinian's Code. Even Great Britain with its common law tradition regarded the law as something that should be memorialised in writing by the likes of Coke, Blackstone and Halsbury. Thus putting laws in writing comported with efforts to "civilise" African lands and people.

The process of recording customary law often fell captive to power and influence. European powers managed and manipulated customary legal systems to their benefit. ${ }^{3}$ By taking an active role in the formalising of indigenous laws and legal systems, the European powers could exercise power and control over their colonial domains through a means that appeared to give deference and autonomy to indigenous people.

Other motivations were more openly pragmatic. Written laws were seen as a means of increasing access to formal justice and providing civil order. Also, if the Europeans were to be in the ultimate sources of power, they needed to understand the rules of the indigenous games they oversaw. ${ }^{4}$

Colonial customary formalisation was not implemented in a uniform manner in sub-Saharan Africa. The sheer number of tribal groups and their languages made the project of customary codification limited and arbitrary. Moreover, each European power had its own legal traditions and distinctive approaches to indigenous engagement.

In some instances, the recording of indigenous law was the result of a particular Western anthropologist's choice to study and record the laws of a particular people. Thorough accounts of customary law appeared within descriptive anthropological works. ${ }^{5}$ Some such efforts took on legal importance as de facto authoritative treatises on the law of the subject people group. In other instances, indigenous laws were reported within formal legal codes generated with the blessing of or in partnership with colonial ruling powers.

The sustained reach of the European colonial project in Africa depended on the use of soft power. Despite advantages in weaponry and political scale, European nations could not maintain effective control over the distant and vast African continent through military might and bureaucratic manpower.

Glenn 1997 Am J Comp L 613.

In the British colonial tradition, the legal concept of "repugnancy" gave colonial arbitrators and administrators the power to disregard indigenous laws and practices if they found them to be offensive to their own moral standards.

5 See, for example, Howell Manual of Nuer Law; and Schapera Handbook on Tswana Law and Custom. 
Other means were needed to exercise effective power and control. Examples included the strategic exploitation of religion, the use of trade, and partnerships with selected tribes for the purpose of exerting influence within a wider geographic sphere. ${ }^{6}$ The hegemonic utilisation of strategic tribal partnerships impacted the existence and extent of colonial era recording of indigenous law.

\section{The formal treatment of customary law in Uganda from colonialism to the present}

The British employed a strategy of selective indigenous engagement in the Uganda Protectorate. ${ }^{7}$ From the onset of their colonial involvement, the British extended favoured status to the Kingdom of Buganda in comparison to other surrounding kingdoms and peoples. ${ }^{8}$

The British granted Buganda significant legal authority and autonomy including the right to legislate in consultation with and approval of the British colonial regime. ${ }^{9}$ Examples of Buganda colonial era legislation include the Buganda Agreement of 1894, Buganda Agreement (Native Laws) of 1913, the Buganda Succession Order of 1926, the Busulu and Envujo Law of 1928, the Buganda Courts Ordinance of 1940 and the Buganda Agreement of $1955 .{ }^{10}$ The abundant issuance of Buganda legal codes and the deference given to the Kingdom set Buganda apart as favoured under British rule in the Protectorate. ${ }^{11}$

Colonial era customary codes were not free from European influence. ${ }^{12}$ In the case of Buganda, there were radical changes in landholding rights under

$6 \quad$ For a discussion of the well-known and ultimately tragic use of this strategy in Rwanda see the first chapter of Reyntjens Political Governance in Post-Genocide Rwanda 1-25.

7 See Morris and Read Uganda 3-81 for an authoritative overview of the legal history of Buganda from the arrival of the European missionaries and the British Empire to the establishment of Uganda as an independent state.

$8 \quad$ McKnight $2000 \mathrm{~J}$ Imp Commonw Hist 66.

$9 \quad$ Haydon Law and Justice in Buganda 21 quoting the decision of Nasanairi Kibuka $v$ AE Bertie 19081 ULR 41 which held in part: "the native Government of Uganda has power to legislate for the subjects of the Kabaka after consultation with and following the advice of the Governor".

10 For a helpful overview of colonial era legislation that impacted land rights in Buganda see Mukwaya Land Tenure in Buganda 15-22.

11 Morris $1972 \mathrm{JAH} 305$. Morris discusses the use of the term "protected rule" as opposed to "indirect rule" to describe the special relationship between the Kabaka of Buganda and the British during the 1930s.

12 While some legal mutations in codified and otherwise recorded customs are relatively easy to trace to colonial influences, other distinctions can be extremely difficult to parse. With each passing generation, it becomes more difficult to discern the customary law from the recorded customary law. Similarly, the actual impact of 
the British Crown. ${ }^{13}$ Moreover, British influence on Buganda succession practices are apparent in the Buganda Succession Order of 1926, which recognises and addresses the use of written wills.

The customary codifications pertaining to Buganda were stripped of any formal legitimacy at the time of Ugandan independence in $1962 .{ }^{14}$ When Uganda became a sovereign nation, the elimination of second-class colonial era citizenship resulted in the laws that formerly applied to the British applying to all Ugandans. So called "native laws" lost their subjects and their legal relevance. By way of example, the Succession Act of 1906 that had initially applied to British subjects became the universal formal law of succession in Uganda and officially displaced contrary and inconsistent customary laws and practices.

However, the transition to national formal laws could not be effectively implemented in lived environments by legal fiat. Customary practices in areas such as succession and guardianships remained dominant in practice and still do to this day. ${ }^{15}$

The colonial era customary codes in Uganda experienced a second formal death after independence. This is because the formal means of establishing, recognising and enforcing customary law did not regard these colonial era codifications as legitimate sources of customary law. Instead, the rules of evidence inherited from the British required that customary law be established based on what the law has been since time immemorial -

colonial era codifications on current beliefs and memories about customary laws and practices is impossible to assess with any specificity.

13 In 1900, the British converted all Buganda Kingdom land into crown land held in the name of Queen Victoria. The land was then granted back in freehold to chiefs and members of the Kabaka's family to hold out for feudal use. These transfers took the tribute and title away from the Kabaka and transferred formal land ownership rights to the local chiefs. See Haydon Law and Justice in Buganda 132-135; Coldham 2000 $J$ Afr L 65-77.

14 The post-independence displacement of customary law did not result in the displacement of the Mailo landholding system established under British rule in Buganda Kingdom lands. Mailo is a hybrid system. It combines aspects of precolonial Buganda customary land tenure with a formal, recoded system of land tenure. It is based on a tribute concept and provides peasants with the opportunity to maintain derivative title in the land that they use and occupy. This unique system of landholding is established through statute and is still in place in modern day Uganda. Section 55 of the Registration of Titles Act, 1924 (Uganda). It is the dominant form of landholding in the historic Buganda lands in south central Uganda.

15 In Mukono District, the formal legal system is largely irrelevant or otherwise inaccessible to most people. By way of example, only 1.3 per cent of widows participate in the mandatory formal estate administration process on their husband's death. IJM Property Grabbing from Ugandan Widows 91. 
i.e. what the law was before it was ever written down. ${ }^{16}$ Thus colonial era customary codes became irrelevant when it came to establishing customary law in a formal court.

Nonetheless, the codes issued for the Kingdom of Buganda under British rule retain effectual resonance despite their non-recognition under the contemporary formal law.

\section{Biases and blind spots hiding the continued role and impact of colonial era customary codifications}

People are influenced by their predispositions. Researchers have a tendency to find what they are looking for and attach an intended significance to those findings. ${ }^{17}$ Similarly, researchers often fail to detect what they are not expecting to see. In the context of academic research, the influence of political sensibilities and existing scholarship can impact the designs and findings of academic field work. ${ }^{18}$

In post-colonial contexts, certain sources of customary law have fallen into political disrepute or have been pushed out of the collective imaginations of the scholars and policy mavens concerned with customary law. This section addresses biases that could cause a researcher to fail to appreciate the contemporary relevance and influence of colonial era customary codifications.

\subsection{Political biases}

Colonialism in Africa is rightly vilified. It is linked to racism, human rights abuses, greed, violence and abuse of power. Colonialism runs counter to broadly embraced political rights such as the right to self-government and a peoples' right to self-determination. As a result, palpable taboos are associated with the work and legacy of colonial enterprises.

Anti-colonialism engenders a collective push to discard all colonial vestiges upon the proverbial "ash heap of history". This push is particularly strong in the context of post-colonial Africa and in the field of indigenous law.

$16 \quad$ Kampala District Land Board and George Mitala v Venansio Babweyaka et al 2008 UCSC App 2 of 2007 (Uganda) upholding Kinyanjui Kimani v Muira Gikanga 1965 EA 735.

17 See generally Beitman 2009 Psychiatric Annals; Swann, Rentfrow and Guinn "SelfVerification" 367-382; Swann, Stein-Seroussi and Giesler 1992 J Pers Soc Psychol; Costin, Dzara and Resch 2011 Psychiatric Annals.

18 See for example Lord, Ross and Lepper 1979 J Pers Soc Psychol; Rothman, Lichter and Nevitte 2005 The Forum. 
However, these biases against colonialism should not distort research or prevent the reporting of findings that speak an ongoing colonial impact.

\subsection{Biases against the formalisation of customary law}

The 1960s and 1970s were marked with various efforts to develop authoritative recordings of customary law in post-colonial Africa. From an access to justice standpoint, there was a belief that such codifications would help to make customary law better known and add to its legitimacy. In the midst of post-colonial pan-Africanism, the prevalent view was that the recording of customary law could be useful in the ongoing de-colonisation project. Although no significant post-colonial customary formalisation initiative took root in Uganda, such efforts were fairly common across Africa. Among the most famous was a nation-wide customary recording project led by Professor Anthony Allot in neighbouring Kenya. ${ }^{19}$

Efforts to formalise customary law face considerable criticism within academic and policy circles. In the wake of the work of Allot and others, Ranger $^{20}$ offered a trenchant and authoritative criticism of the invention of distorted versions of customary law in colonial Africa. Today, the transcription, proof and formal practice of customary law remains susceptible to abuses of power and influence. ${ }^{21}$

The formalisation of customary law is further critiqued as an exercise that strips the ownership of legal customs from the people on the ground to those managing the drafting process. Thus thought and policy leaders in the academic and policy circles commonly consider the recording of customary law to be antithetical to its adaptive and communal essence. ${ }^{22}$

However, the tendency of authoritative renditions of customary law to be flawed or illegitimate does not warrant disregard of the potential role and impact of colonial era customary codes. On the contrary, such concerns make their impact all the more important to consider and assess.

\footnotetext{
19 See Allot "Introduction" xi-xv for a description of this process by Professor Allot.

20 Ranger "Invention of Tradition in Colonial Africa" 247-252.

21 See Claasens and Mnisi 2009 SAJHR 491-516. This article addresses the tendency of men to play dominant roles in defining custom, rights and customary entitlements by offering proposals for engaging women in those roles to address this gendered power imbalance. 


\subsection{Pro-formalist biases}

While biases against formalism in customary contexts can engender disregard for colonial-era customary codes, biases for legal formalism and assumptions about a progression towards increasing legal formalism can also prevent legal observers from detecting and appreciating the ongoing role and influence of such codes.

\subsubsection{The formalist approach to establishing customary law in Uganda}

The evidentiary approach to proving customary law in Uganda directs judges to only recognise customary law as it existed from "time immemorial". This requirement makes colonial era customary codes irrelevant in a formal court.

Requiring that a law not be in writing is antithetical to legal formalism. However, it is the formal law itself that has imposed this "time machine" requirement on the appointed cultural diviners of customary law. As the prewritten existence of African indigenous people groups drifts further into the past, the more challenging it becomes to prove and establish customary law. In the end, the seemingly informal requirement of "time immemorial" makes the informal law effectively irrecoverable and thereby effectively irrelevant.

\subsubsection{The presumption of progress towards formalism}

There is a contemporary emphasis on legal formalism and its capacity to bring access to justice and transformative change. This emphasis to promote access to justice is particularly strong in globalist and Western initiatives. The United Nations ${ }^{23}$ publication Making the Law Work for Everyone is emblematic of this effort where enabling increasing numbers of presently disenfranchised poor to access the formal justice sector is the desired endgame. Similarly, Haugen and Boutros ${ }^{24}$ stress the need for legal accountability to build and maintain a functioning and productive society.

A core component in access to justice initiatives is the widespread dissemination of formal legal literacy. One ubiquitous means of increasing legal knowledge at the community level is grassroots legal education. In Uganda, those educational activities are referred to as legal sensitisations.

23 UN Commission on the Empowerment of the Poor Making the Law Work for Everyone 59-64.

24 Haugen and Boutros Locust Effect 274-275. Mr Haugen is the Chief Executive Officer of International Justice Mission. This particular NGO's work and research in Mukono District is discussed in section 5.3 of this paper. 
Proponents and practitioners of legal sensitisation seek to bridge the knowledge gap between people's understandings and the formal law through the steady sharing of the formal law to local leaders and community members by informed outsiders and formal actors. Public access to the formal legal system is presumed to increase and improve over time through the dissemination of formal legal knowledge.

Those who share in the suppositions described above are not attuned to appreciate the impact of colonial era customary codes on community-level legal knowledge when those codes set forth rules and legal principles consistent with the current formal law. Instead, any consistent understanding is reflexively attributed to the inculcation of right knowledge of the formal law. This is despite the fact that formal law might have no causal relationship with a congruent understanding of the law. Moreover, those with this bias are also more likely to attribute beliefs that are inconsistent with the formal law to longstanding cultural beliefs as opposed to attributing them to a pre-existing legal source. An anecdotal illustration of how such biases concerning the sourcing of legal knowledge and awareness can impact the ability to detect the potential role and impact of colonial-era customary codes is provided in sub-section 5.3 below.

\section{Discovering the resonance of customary codifications}

Having accounted for the biases and blind spots that prevent researchers from attending to the resonance of colonial era customary codes, this next section unpacks particular reasons for the author's discovery of the same in Mukono District. ${ }^{25}$

\subsection{The receptivity of Moore's semi-autonomous social field}

This paper springs from research conducted in connection with the author's doctoral thesis entitled The Status, Rights and Treatment of Persons with Disabilities within Customary Legal Frameworks in Uganda: A Study of Mukono District. ${ }^{26}$

The originating research project required a methodology open to unexpected findings and capable of accounting for a broad palate of legal

25 Mukono District is located in Central Uganda, east of the capital city of Kampala and north of Lake Victoria. Mukono is a traditional indigenous home to the Baganda people although other tribal groups now inhabit the district as well due to increased mobility within Uganda. Mukono District is located in a transitional area that includes semi-urban towns within the suburban expansion of greater Kampala as well as rural areas.

26 Dennison Status, Rights and Treatment of Persons with Disabilities. 
influences. Sally Falk Moore's ${ }^{27}$ work on the semi-autonomous social field provided valuable technical guidance with respect to the research design. Moore's ${ }^{28}$ approach is resilient against biases and preconceptions especially when it comes to the validity and potency of sources of law. Aligning the research approach with Moore's design insights helped to protect the fieldwork from the influence of academic orthodoxy, political values and personal biases. At the same time, the open and researchguided field work created the space needed to make unexpected findings.

\subsection{Reading Haydon}

Reading Law and Justice in Buganda by Haydon in connection with my doctoral deskwork felt anachronistic. The 1960 text was published two years before Ugandan independence by a non-Ugandan. It is a relatively dated work by a cultural outsider.

Had there been similarly comprehensive treatments of Baganda customary law of a more recent vintage, the Haydon book might have received no more than a cursory read. Yet as other reading materials had failed to render Haydon non-essential, I set aside my own biases against the text and spent a considerable amount of time reading Haydon's book.

Although Haydon ${ }^{29}$ primarily addressed observed cultural and customary practices, he did not disregard the existence and importance of colonial era customary codifications. He referenced these codifications in his text and included them in appendices. ${ }^{30}$

Based on other initial reading, I was predisposed against the relevance of these colonial era customary codes. Yet, as the research progressed, the need to take stock of colonial era codifications of Buganda customary law became apparent.

\subsection{IJM field research in Mukono District}

Another circumstance that brought out the relevance and resonance of colonial era customary codifications arose out my involvement and

$27 \quad$ Moore 1973 Law \& Soc'y Rev 745.

28 The research project was rife with orthodoxies and biases that inhabit the subjects of disability studies, African customary law and human rights. See, for example, Oliver Politics of Disablement; Hahn 1993 J Disabil Policy Stud 41-52; Mollow 2004 MQR 269-296; Woodman $1998 \mathrm{~J}$ Legal Plur; Leonardi et al $2011 \mathrm{~J}$ Legal Plur.

29 Haydon Law and Justice in Buganda xxiii (Table of Legislation).

30 A compendium that includes various colonial era Buganda legal codes is available in Mukwaya Land Tenure in Buganda 15-22. 
engagement with a non-governmental organisation known as International Justice Mission (IJM). ${ }^{31}$

IJM is an American non-governmental organisation motivated by a Biblical mandate to seek justice. ${ }^{32}$ It describes itself as "a global organisation" dedicated to "protecting the poor from violence throughout the developing world". ${ }^{33}$ Access to justice through the formal sector is at the core of IJM founder Gary Haugen's ${ }^{34}$ strategy to combat injustice.

IJM establishes partnerships with local authorities to address injustices experienced by vulnerable people. ${ }^{35}$ Its model for promoting transformative change begins by identifying scenarios where the formal law of a nation has the capacity to bring about positive change. IJM justice initiatives involve the strategic leveraging of the formal law's capacity to stop and redress ongoing injustices. IJM combats sex trafficking in Cambodia and the Philippines by bringing resources alongside the criminal justice system. It combats slavery in India through similar means. In Uganda, IJM addresses the widespread practice of taking of land from widows and their children when the male head of their household dies. IJM refers to this phenomenon as "property-grabbing".

Ugandan law has numerous provisions in the formal law that forbid the practice of property grabbing. ${ }^{36}$ IJM combats the practice through a multipronged approach which includes community sensitisation, will-writing clinics, the support of local law enforcement to address "property grabbing" as a criminal enterprise, and the litigation of civil cases on behalf of victims. IJM hopes that correct and widespread knowledge of the formal law along with access to justice will help to reduce the practice of property grabbing and protect widows and their children. ${ }^{37}$

IJM's efforts to combat property grabbing began in Mukono District over a decade ago. ${ }^{38}$ In 2008, IJM completed an initial baseline study in Mukono

31 The author became familiar with IJM primarily though his work as a coordinator of clinical legal education at Uganda Christian University where law students assisted IJM in various field work activities.

32 Haugen Good News about Injustice 175.

33 IJM Property Grabbing from Ugandan Widows 112.

$34 \quad$ Haugen and Boutros Locust Effect 244-257.

$35 \quad$ IJM Property Grabbing from Ugandan Widows 112.

$36 \quad$ IJM Property Grabbing from Ugandan Widows 15-16.

37 IJM Property Grabbing from Ugandan Widows 12.

38 Over the past several years IJM has expanded its operations in Uganda to address post-conflict areas in Northern Uganda around Gulu. 
District prior to beginning its work. ${ }^{39}$ The study investigated the extent of property grabbing in Mukono District, people's knowledge of the formal laws that protect against property grabbing, and people's willingness and ability to engage the formal legal system to address property grabbing. Based on its initial study, IJM rolled out its multi-pronged effort described in the previous paragraph.

In 2014, IJM concluded a more expansive study in Mukono District. ${ }^{40}$ The stated purpose of the survey was as follows:41

... to document the prevalence and impact of property grabbing among widows in Uganda and the effectiveness of the Ugandan public justice system's response to property grabbing.

The study's participants were asked questions about Ugandan law. IJM sought to assess the grass-roots knowledge of formal Ugandan law relevant to succession and land-grabbing. ${ }^{42}$

The results of IJM's study in terms of community legal knowledge was mixed. ${ }^{43}$ In some instances, there was a relatively high level of knowledge about relevant laws while in other areas the knowledge was relatively low. ${ }^{44}$ The IJM study attributed the inconsistencies in community member legal knowledge to various factors including a lack of exposure to the formal law and the distorting impact of "entrenched ideas and practices of customary law". ${ }^{45}$ However, IJM did not offer specific explanations for what appeared to them to be relatively arbitrary discrepancies with respect to legal knowledge. ${ }^{46}$ In particular, IJM was perplexed by relatively high awareness levels of certain laws that did not appear to be indigenous or traditional. Examples of such laws with broad grass-roots appreciation included the recognition of written wills and the right of widows and their children to stay in marital homes after a husband's death.

The IJM study included no reference to or accounting for the colonial era customary codes of the Buganda Kingdom. Non-formal legal knowledge was attributed to the blanket category of "cultural beliefs" or ignorance of

39

40

41

42

43

44

45

46

The author personally attended the presentation of this paper in a Mukono government building in late 2008.

IJM Property Grabbing from Ugandan Widows 10. The author attended the public presentation of this study in Kampala.

IJM Property Grabbing from Ugandan Widows 10.

IJM Property Grabbing from Ugandan Widows 10.

IJM Property Grabbing from Ugandan Widows 92-93.

IJM Property Grabbing from Ugandan Widows 58 (table 17), 67 (table 21).

IJM Property Grabbing from Ugandan Widows 16-17.

IJM Property Grabbing from Ugandan Widows 92. 
the law. ${ }^{47}$ Yet a key for the surprising inconsistencies in the community's legal knowledge could be found in the unmentioned - and presumably unaccounted for - colonial era Buganda codes.

In instances where there was a high level of knowledge about seemingly progressive or formalistic practices such the legitimisation of written wills, ${ }^{48}$ protecting the rights of the formally unmarried, and provisions that provide widows and orphans with the right to stay in the marital home, such practices are pronounced in colonial era Buganda legislation. ${ }^{49}$ Meanwhile, more "regressive" practices that community members continued to view as law such as not allowing women to inherit family land and expansive powers assigned to the customary heir also appear in colonial era codifications. ${ }^{50}$ What the IJM research team presumed to be a mix of partial knowledge of the formal law and incorrect cultural beliefs appears instead to be a resilient knowledge of colonial era codifications. ${ }^{51}$

IJM's study is representative of the default presumption of progress towards formalism described in section 4.3.2. The IJM research did not consider the possibility that consistencies between beliefs about the law and the formal law were attributable to pre-existing customary codifications. They adhered to default view that a legal understanding consistent with the formal law flows from the top-down dissemination of formal law. However, this view is based on an untested assumption. "Correct" answers about the substance of the formal law can also be the product of consistencies with pre-existing legal knowledge.

$47 \quad$ IJM Property Grabbing from Ugandan Widows 16-17.

48 Colonial codifications concerning written wills merit close attention because the practice of written will writing did not arise until after the arrival of the British. Therefore, it is clear that some portion of Buganda's colonial era codification of customary law was not indigenous. The extent to which the British modified or supplemented customary law and practice through the codification process is beyond the scope of this paper.

49 Haydon Law and Justice in Buganda 222-223, 320-325.

50 See for example s 12 of the Succession Order, 1926 and its Schedule Vida Clause II.

51 A review of colonial era codifications also helped the author make sense of earlier experiences in community will writing clinics the author organised with Ugandan law students. For example, some participants had asked whether a will had to be written in Luganda and stated that they thought that a will written in English was invalid. The fact that people has this understanding of the law made sense to me when I read $s$ 4 of the Succession Order, 1926 which requires that "wills must be legally written in the Native Language of Luganda". 


\subsection{Field interviews pointing to "dark matter"}

Dark matter is the unknown substance that astro-physicists presume to exist because the existence of that matter is necessary to maintain the legitimacy of their knowledge and observations. ${ }^{52}$ Astro-physicists have not seen dark matter, but they are confident it must exist based on the operation of gravity and the current reckoning of observable matter in the universe. Although they cannot detect it directly, the scientists can detect it indirectly based on how it impacts the physical matter they can observe.

The detection of dark matter has certain parallels with the detection of customary legal codifications in my interviews of individuals knowledgeable about Baganda customary law. ${ }^{53}$ Although the interview subjects never referenced a colonial era customary code directly, the ongoing role and impact of these codes became apparent based on the conduct and answers of the subjects.

Many interview subjects deemed to be knowledgeable about Bugandan custom indicated that there were objective right answers when it came to the substance of Buganda customary law. They would search their memory for a correct answer. They gave the impression that the law was clear, official and long-standing. At the same time, they did not give the impression that they were trying to recall the ways things have been since time immemorial.

In addition, these interview subjects did not treat the current views and practices of the community as authoritative on the substance of Buganda customary law. Instead, they searched their memory for the substance of authoritative content. They would refer to a legal principle as being "there" - saying things such as "that one is there". They seemed to be referencing an official rendering of law that served as the basis of the official customary law of the Baganda people. Some interviewees indicated that this official rendering could be accessed if enough effort was applied. However, at no time did an interview subject present me with a written version of this source.

Familiarity with the colonial-era codifications enabled me to connect the interviewees' sense of customary orthodoxy with the once-official

\footnotetext{
52 Siegel 2018 https://www.forbes.com/sites/startswithabang/2018/10/05/this-is-thereal-reason-we-havent-directly-detected-dark-matter/\#3b83942432f2.

53 During the research process certain individuals were identified as being knowledgeable about the Baganda customary law. These individuals were interviewed as authoritative figures based on their status in both the community and their knowledge of Baganda customs and practices.
} 
codifications. When I reviewed the IJM findings discussed in sub-section 5.3 in light of this connection, the "dark matter" of the resonance and resilience of colonial era customary codes was too impactful to ignore.

\section{Reasons for colonial code resilience in Mukono District}

Certain factors make colonial era customary codes particularly resilient in Mukono District. They are discussed below.

\subsection{Home-language advantage}

English is an official language in Uganda, but it is not the language the vast majority of people regularly speak. The "mother tongue" of the Baganda people and the majority of people living in Mukono District is Luganda.

Given its home-language advantage, the resilience and resonance of colonial era codifications should not come as a surprise. Colonial era codes of the Buganda Kingdom were regularly issued in Luganda. On the other hand, formal Ugandan law is written in English and it has never been officially translated into an indigenous language. In fact, it is difficult to find versions of the Ugandan Constitution drafted in most of Uganda's dozens of indigenous languages despite the fact that its Constitution, promulgated in 1995 , provides that: 54

The State shall promote public awareness of this Constitution by translating it into Ugandan languages and disseminating it as widely as possible.

The fact that customary codifications were published in Luganda is important. Even if people never read a customary code, the ability to fact state and share the official substance of the customary code directly in Luganda is significant. If the law is only written in English, it is far less likely to be translated and shared by people who are not comfortable conversing or reading in English.

\subsection{The written word and the displacement of memory}

There are no official versions of customary law in modern-day Uganda. Instead, Ugandan courts require litigants to establish the historic substance of customary law through expert oral testimony. ${ }^{55}$ According to the formal law, to be deemed competent to testify about the substance of customary law, a witness must be considered an expert on customary law by

Article 4 of the Constitution of Uganda, 1995.

Kinyanjui Kimani v Muira Gikanga 1965 EA 735; Jok, Leitch and Vandewint Study of Customary Law 12. 
community members. ${ }^{56}$ This evidentiary approach for establishing customary law arose when older men were deemed stewards of the communal memory concerning life before the British arrived. The customary law they were called to testify about was the law as it existed before the arrival of the written English word. This is referred to as "time immemorial".

Uganda's evidentiary requirement that customary law be the law as it has existed since "time immemorial" reserves formal legitimacy to the customary law as it existed before the arrival of the British. Yet as time passes, the myth of the pristine pre-colonial cultural memory moves further and further outside the range of any plausibility structure. The memories of living Ugandans can no longer stretch back to times predating the adoption of the Buganda Kingdom codes such as the Succession Order of 1926. Thus there is no longer any living memory of "time immemorial" that predates the transcription of customary law into the written word.

The existence of colonial codifications of customary law in the Baganda cultural fabric place the legitimacy of the memory of pre-written law squarely in the dock. Memory - both personal and collective - has been at the centre of the process of discerning customary law in Uganda. Yet what is the source of a memory once written artefacts displace lived narratives? Twenty-first century cultural memories about the substance of customary law are now most certainly supplied, influenced or otherwise tainted by recorded media. Among the Baganda, the most formative and historically effectual written media depicting customary law are the colonial era customary codifications of the Buganda Kingdom. The role of the codifications in forming customary orthodoxy at the community level should not come as a surprise.

\subsection{The Kabaka as lawmaker}

Louis XIV of France is famous - or infamous - for saying "L'etat c'est moi" ("I am the State"). Although this assertion was a pointed overstatement, certainly the Sun King was more than just a man. As Marin ${ }^{57}$ argues, Louis XIV's effectual sovereign status helped to make his own ideas about life the ideas and practices of his people.

Among the Baganda people, the Kabaka, their king, is also more than just a man. In a Kelsenian ${ }^{58}$ sense, the Kabaka has long occupied the status of

\footnotetext{
56 Section 48 of the Evidence Act 6 of 1909.

57 Marin Portrait of the King 13-15.

58 See generally Kelsen General Theory of Law and State; Kelsen General Theory of Norms; and Kelsen Pure Theory of Law.
} 
legal grundnorm within the Kingdom of Buganda. Historically the Kabaka has had the unquestioned authority to create and change Buganda law. ${ }^{59}$

During the era of British Colonisation, the Kabaka's power was conditional on British oversight and approval. ${ }^{60}$ The colonial era codification process is an example of how the law-making authority of the Kabaka became subject to the British Crown. After Ugandan independence in 1962 and the subsequent "Buganda crisis" of 1966, the unilateral law-making authority of the Kabaka was stripped of formal recognition by the new Ugandan state. ${ }^{61}$ After that time, Uganda's indigenous kings and clan leaders were stripped of their formal political power and reduced to cultural figureheads within the national governing structure. ${ }^{62}$

Even so, the Kabaka remains the chief customary law-maker of the Baganda people. ${ }^{63}$ Although the Kingdom of Buganda is a largely ceremonial and cultural institution at this time, there is a prevalent belief that it is still the Kabaka who makes and changes the Baganda customary law. More than that, the Kabaka is seen as the living embodiment of the law or lawful authority when it comes to Baganda customary law.

The persistent power of the Kabaka could be considered regressive. ${ }^{64}$ Patrilineal power runs counter to the claims that true customary law is - or

$59 \quad$ Dennison Status, Rights and Treatment of Persons with Disabilities 108.

60 Haydon Law and Justice in Buganda 21 quoting the decision of Nasanairi Kibuka $v$ AE Bertie 19081 ULR 41 which held in part: "the native Government of Uganda has power to legislate for the subjects of the Kabaka after consultation with and following the advice of the Governor". In the specific context of disabilities rights, field interviewees spoke of past Kabakas who initiated changes in rights and treatment of persons with disabilities under customary law. Dennison Status, Rights and Treatment of Persons with Disabilities 188-189. Interestingly, these Kabaka-directed changes were accomplished by fiat and tended to address the plight of specific family members and loved ones with disabilities.

$61 \quad$ First 1971 World Today.

62 Many field interviewees lamented the diminishment and marginalisation of customary legal institutions. They referred to institutions that were established to ensure that Buganda ways and practices were followed. Yet they acknowledged that those institutions are underfunded and understaffed. Dennison Status, Rights and Treatment of Persons with Disabilities 188-189. Thus, beyond the figure heads of the Kabaka and the prime minister (Katikiro), there are few tangible and respected figures and institutions to point to within the Buganda Kingdom.

63 Dennison Status, Rights and Treatment of Persons with Disabilities 189, 196, 210.

64 The author is familiar with those who have argued that the Buganda royal line is matriarchal and not patriarchal. This is because there is a requirement that the mother of the Kabaka must come from other clans. Yet it is clear that men are dominant in terms of customary leadership and oral headship among the Baganda. 
at least can be - more communal, more egalitarian and less sexist than it has been portrayed. ${ }^{65}$

Yet when it comes to the substantive customary law of the Baganda, there is a clear recognition that the Kabaka has the power to make and change that law. While there might be differences of opinion as to what the customary law might be, there is no disagreement that Baganda customary law is what the Kabaka declares it to be.

Thus to the extent the Kabaka played a role in establishing colonial era codifications in conjunction with the British, those formal codifications have grassroots legitimacy based on the Baganda people's concept of law. Since the Kabaka had the undisputed mandate to declare the law, any codification of the customary law that received the Kabaka's approval could be accepted as a legitimate expression and establishment of Baganda customary law.

Thus in the broader historic context, the colonial era codifications of Buganda Law are arguably the apex of the written law in the kingdom. This defies modern presumptions that might see such laws as outdated, politically tainted and culturally illegitimate.

\section{Conclusion and broader implications}

This paper does not entail a thorough and expansive study of colonial era customary codes on a global or pan-African level. Instead, it presents a singular and relatively fortuitous appreciation about the ongoing resilience of such codes in Mukono District.

The paper posits that current conceptions of Baganda customary law are informed and shaped by the colonial era codifications promulgated by the British Protectorate and the Kingdom of Buganda. This core finding is limited in scope. It should not serve as the basis of sweeping conclusions about the continued importance of colonial era customary codes in other contexts. However, broader implications flow from that limited finding and the analysis put forward in this paper.

Scholars, researchers, policy makers and change agents should be open to the continuing role of colonial era customary codifications within modern semi-autonomous social fields. Such codes have the potential to be influential and durable legal artefacts. This is especially true in instances where the codifications were published in a still dominant indigenous

65 See for example Kalabamu 2009 Dev South Afr. 
language and the current formal law has never been translated into that language.

To look to a colonial era customary code as culturally authoritative or currently relevant is contra to the post-colonial orthodoxy. As the formal transcription of customary law in Africa has fallen into disfavour, ${ }^{66}$ colonial era customary codifications register somewhere between objectionable artefacts and anathema. Yet, the resilience of colonial era codifications in Mukono District is a phenomenon that should be accounted for regardless of their disfavoured status.

If legal and policy actors put aside the myth of pristine indigenous law, they can take proper stock of the content that generates and forms effectual conceptions of customary law. When encountering and assessing human descriptions and depictions of indigenous law, it is useful to consider legal artefacts with alien pedigrees. In addition, although customary law is certainly "living law" in the sense that is subject to continuous change as well as continuous use, customary law is undoubtedly grounded in and validated by tradition and past practice.

Colonial era codifications of customary law - especially those codified in indigenous first languages - have the capacity to form and inform living customary law. Even if these codifications are only known through memory, they can continue to exercise an authoritative influence as to what the customary law has always been and therefore should be. Thus, those looking to discern the sourcing and content of customary law should account for the possible impact and influence of colonial era codifications. Misgivings about the oppressive influences and exploitative motivations that played a role in the development of these colonial era codes should not serve as a basis for disregarding their role within modern customary legal frameworks.

The paper also shines critical light on presumptions regarding the dissemination of legal knowledge. As seen in the IJM study, some presume that community knowledge consistent with the formal law is the product of the successful transmittal of formal legal knowledge. However, that presumption can prove false. To appreciate the basis of a community's legal understanding, it is important to account for sources of legal knowledge that predate the formal law. Had IJM appreciated the resonance of colonial era customary codes in Mukono District, it could have added considerable depth and insight to its findings regarding community member legal knowledge.

66 See Ranger "Invention of Tradition in Colonial Africa" 247-252. 
Moreover, such knowledge could have enhanced IJM's strategy for addressing the challenge of property grabbing.

Prevailing orthodoxies have the potential to exert profound and pervasive influence over social science research. Research that affirms politicised conventions offers the path of least resistance. Yet receptive and openended fieldwork can help generate valuable findings and insights that have the potential of resisting biases. Moore's ${ }^{67}$ semi-autonomous social field research approach and other similar approaches provide a means of arriving at findings despite the sway of politically charged orthodoxies. ${ }^{68}$

A related tenet of Moore's semi-autonomous social field is the importance of contextual specificity. Culture and history are inherently idiosyncratic. What holds true for one place and people at a certain time may not hold true for other places, peoples and times. For example, this paper addresses how the law-making power of the Kabaka, the unique hegemonic relationship between the Kingdom of Buganda and the British, and the failure to bridge the language gap between the formal law and the people of Mukono District impact the ongoing role of colonial era customary codes. Those details matter. They underline the importance of the singular context that Moore applies to descriptive legal research in highly pluralistic settings.

\section{Bibliography}

\section{Literature}

Allot "Introduction"

Allot A "Introduction" in Cotran E (ed) Case Book on Kenya Customary Law (Nairobi University Press Nairobi1987) xi-xv

Beitman 2009 Psychiatric Annals

Beitman B "Brains Seek Patterns in Coincidences" 2009 Psychiatric Annals 255-264

Bennett and Vermeulen $1980 \mathrm{~J}$ Afr $L$

Bennett TW and Vermeulen T "Codification of Customary Law" $1980 \mathrm{~J}$ Afr L 206-219

67 Moore 1973 Law \& Soc'y Rev 723, 740.

$68 \quad$ Griffiths $1986 \mathrm{~J}$ Legal Plur 3-4, 39. 
Claasens and Mnisi 2009 SAJHR

Claasens A and Mnisi S "Rural Women Redefining Land Rights in the Context of Living Customary Law" 2009 SAJHR 491-516

Coldham $2000 \mathrm{~J}$ Afr L

Coldham S "Land Reform and Customary Rights: The Case of Uganda Reviewed" 2000 J Afr L 65-77

Costin, Dzara and Resch 2011 Psychiatric Annals

Costin G, Dzara K and Resch D "Synchronicity: Coincidence Detection and Meaningful Life Events" 2011 Psychiatric Annals 572-575

Cotula "Introduction"

Cotula L "Introduction" in Cotula L (ed) Changes in "Customary" Land Tenure Systems in Africa (IIED London 2007) 1-14

Dennison Status, Rights and Treatment of Persons with Disabilities

Dennison DB The Status, Rights and Treatment of Persons with Disabilities within Customary Legal Frameworks in Uganda: A Study of Mukono District (PhD thesis University of Cape Town 2017)

First 1971 World Today

First R "Uganda: The Latest Coup D'état in Africa" 1971 The World Today 131-138

Glenn 1997 Am J Comp L

Glenn HP "The Capture, Reconstruction and Marginalization of Custom" 1997 Am J Comp L 613-620

Griffiths 1986 J Legal Plur

Griffiths J "What is Legal Pluralism?" $1986 \mathrm{~J}$ Legal Plur 1-55

Hahn 1993 J Disabil Policy Stud

Hahn H "The Political Implications of Disability Definitions and Data" $1993 \mathrm{~J}$ Disabil Policy Stud 41-52

Haugen Good News about Injustice Haugen G Good News about Injustice: A Witness of Courage in a Hurting World (InterVarsity Downers Grove 2002)

Haugen and Boutros Locust Effect Haugen G and Boutros V The Locust Effect (Oxford University Press London 2014) 
Haydon Law and Justice in Buganda

Haydon ES Law and Justice in Buganda (Butterworths London 1960)

Howell Manual of Nuer Law

Howell PP A Manual of Nuer Law (Oxford University Press London 1954)

IJM Property Grabbing from Ugandan Widows

International Justice Mission Property Grabbing from Ugandan Widows and the Justice System: A Mixed-Methods Assessment in Mukono County, Uganda (International Justice Mission Washington DC 2014)

Jok, Leitch and Vandewint Study of Customary Law

Jok AA, Leitch R and Vandewint C A Study of Customary Law in Contemporary Southern Sudan (World Vision International and the South Sudan Secretariat of Legal and Constitutional Affairs Nairobi 2004)

Kalabamu 2009 Dev South Afr

Kalabamu FT "Towards Egalitarian Inheritance Rights in Botswana: The Case of Tlokweng" 2009 Dev South Afr 209-223

Kelsen General Theory of Law and State

Kelsen $\mathrm{H}$ General Theory of Law and State (Wedberg A translation) (Russell \& Russell New York 1961)

Kelsen General Theory of Norms

Kelsen H General Theory of Norms (Hartney M translation) (Clarendon Press Oxford 1991)

Kelsen Pure Theory of Law

Kelsen $\mathrm{H}$ Pure Theory of Law (Knight M translation) (Berkley University of California Press 1967)

Leonardi et al $2011 \mathrm{~J}$ Legal Plur

Leonardi C et al "The Politics of Customary Law Ascertainment in South Sudan" $2011 \mathrm{~J}$ Legal Plur 111-142

Lord, Ross and Lepper $1979 \mathrm{~J}$ Pers Soc Psychol

Lord CG, Ross L and Lepper MR "Biased Assimilation and Attitude Polarization: The Effects of Prior Theories on Subsequently Considered Evidence" 1979 J Pers Soc Psychol 2098-2109

Marin Portrait of the King

Marin L Portrait of the King (Houle M translation) (McMillan London 1988) 
McKnight $2000 \mathrm{~J}$ Imp Commonw Hist

McKnight GH "Land, Politics, and Buganda's 'Indigenous' Colonial State" $2000 \mathrm{~J}$ Imp Commonw Hist 65-89

Mollow 2004 MQR

Mollow A "Identity Politics and Disability Studies: A Critique of Recent Theory" 2004 MQR 269-296

Moore 1973 Law \& Soc'y Rev

Moore SF "Law and Social Change: The Semi-Autonomous Social Field as an Appropriate Subject of Study" 1973 Law \& Soc'y Rev 719-746

Morris $1972 \mathrm{JAH}$

Morris HF "Sir Philip Mitchell and 'Protected Rule' in Buganda" 1972 JAH 305-323

Morris and Read Uganda

Morris HF and Read JS Uganda: The Development of its Laws and Constitution in The British Commonwealth: The Development of its Laws and Constitutions (Stevens and Sons London 1966) v 13

Mukwaya Land Tenure in Buganda

Mukwaya AB Land Tenure in Buganda (Eagle Press Kampala 1953)

Oliver Politics of Disablement

Oliver M The Politics of Disablement: A Sociological Approach (St Martin's Press New York 1990)

Ranger "Invention of Tradition in Colonial Africa"

Ranger $T$ "The Invention of Tradition in Colonial Africa" in Hobsbawm E and Ranger $\mathrm{T}$ (eds) The Invention of Tradition (Cambridge University Press Cambridge 1983) 211-263

Reyntjens Political Governance in Post-Genocide Rwanda

Reyntjens F Political Governance in Post-Genocide Rwanda (Cambridge University Press Cambridge 2013)

Rothman, Lichter and Nevitte 2005 The Forum

Rothman S, Lichter SR and Nevitte $N$ "Politics and Professional Advancement among College Faculty" 2005 The Forum - De Gruyter 1-16

Schapera Handbook on Tswana Law and Custom

Schapera I A Handbook on Tswana Law and Custom (Oxford University Press London 1938) 
Shadle $1999 \mathrm{JAH}$

Shadle B "'Changing Traditions to Meet Current Altering Conditions': Customary Law, African Courts and the Rejection of Codification in Kenya, 1930-1960" 1999 JAH 411-431

Swann, Rentfrow and Guinn "Self-Verification"

Swann WB, Rentfrow PJ and Guinn JS "Self-Verification: The Search for Coherence" in Leary MR and Tangney JP (eds) Handbook of Self and Identity (Guilford Press New York 2003) 367-383

Swann, Stein-Seroussi and Giesler 1992 J Pers Soc Psychol

Swann WB, Stein-Seroussi A and Giesler RB "Why People Self-Verify" 1992 J Pers Soc Psychol 392-401

UN Commission on the Empowerment of the Poor Making the Law Work for Everyone

United Nations Commission on the Empowerment of the Poor Making the Law Work for Everyone (United Nations New York 2008)

Woodman $1998 \mathrm{~J}$ Legal Plur

Woodman GR "Ideological Combat and Social Observation: Recent Debate about Legal Pluralism" 1998 J Legal Plur 21-59

\section{Case law}

Kampala District Land Board and George Mitala v Venansio Babweyaka et al 2008 UCSC App 2 of 2007 (Uganda)

Kinyanjui Kimani v Muira Gikanga 1965 EA 735

Nasanairi Kibuka v AE Bertie 19081 ULR 41

\section{Legislation and colonial treaties}

Buganda Agreement, 1894

Buganda Agreement (Native Laws), 1913

Buganda Agreement, 1955

Buganda Courts Ordinance, 1940

Busulu and Envujo Law, 1928

Constitution of Uganda, 1995 (as amended in 2005) 
Evidence Act 6 of 1909 (Uganda)

Registration of Titles Act, 1924 (Uganda)

Succession Act, 1906 (Uganda)

Succession Order, 1926 (Buganda)

\section{Internet sources}

Siegel 2018 https://www.forbes.com/sites/startswithabang/2018/10/05/thisis-the-real-reason-we-havent-directly-detected-darkmatter/\#3b83942432f2

Siegel E 2018 This is the Real Reason we haven't Directly Detected Dark Matter https://www.forbes.com/sites/startswithabang/2018/10/05/this-isthe-real-reason-we-havent-directly-detected-dark-matter/\#3b83942432f2 accessed 4 November 2019

\section{List of Abbreviations}

\begin{tabular}{|c|c|}
\hline Am J Comp L & American Journal of Comparative Law \\
\hline Dev South Afr & Development Southern Africa \\
\hline IJM & International Justice Mission \\
\hline J Afr L & Journal of African Law \\
\hline J Disabil Policy Stud & Journal of Disability Policy Studies \\
\hline $\mathrm{J}$ Imp Commonw Hist & $\begin{array}{l}\text { Journal of Imperial and Commonwealth } \\
\text { History }\end{array}$ \\
\hline J Pers Soc Psychol & Journal of Personality and Social Psychology \\
\hline J Legal Plur & Journal of Legal Pluralism and Unofficial Law \\
\hline JAH & Journal of African History \\
\hline Law \& Soc'y Rev & Law and Society Review \\
\hline MQR & Michigan Quarterly Review \\
\hline SAJHR & South African Journal on Human Rights \\
\hline & United Nations \\
\hline
\end{tabular}

